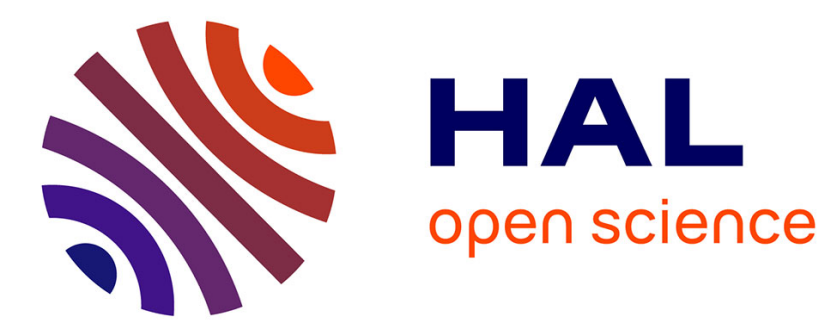

\title{
Peer Production and Social Change
}

Mathieu O'Neil, Sebastien Broca

\section{To cite this version:}

Mathieu O'Neil, Sebastien Broca. Peer Production and Social Change. Mathieu O'Neil; Christian Pentzold; Sophie Toupin. The Handbook of Peer Production, Wiley, pp.285-298, 2020, 978-1-11953710-6. 10.1002/9781119537151.ch21 . hal-03146656

\section{HAL Id: hal-03146656 https://hal.science/hal-03146656}

Submitted on 19 Feb 2021

HAL is a multi-disciplinary open access archive for the deposit and dissemination of scientific research documents, whether they are published or not. The documents may come from teaching and research institutions in France or abroad, or from public or private research centers.
L'archive ouverte pluridisciplinaire HAL, est destinée au dépôt et à la diffusion de documents scientifiques de niveau recherche, publiés ou non, émanant des établissements d'enseignement et de recherche français ou étrangers, des laboratoires publics ou privés. 
This is the author's version of a chapter accepted for publication in the Handbook of Peer Production. Changes resulting from the publishing process such as copy-editing, typesetting, and other quality control mechanisms may not be reflected in this document. This author manuscript version is available for personal, non-commercial and no derivative uses only.

Citation: O'Neil, M. \& Broca, S. (2020). Peer production and social change. In: M. O'Neil, C. Pentzold \& S. Toupin (Eds.), The Handbook of Peer Production (pp. 285-298). Malden, MA: Wiley-Blackwell.

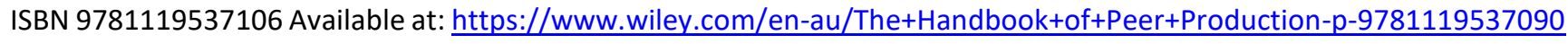

The Handbook of Peer Production

Chapter 21 - Peer Production and Social Change

Mathieu O’Neil, University of Canberra, Australia

\& Sébastien Broca, Université Paris 8, France 


\section{Introduction}

This chapter examines actions seeking to address the social harms of neoliberal capitalism as well as the democratic failures of the centralized state. Our main concern is whether peer production, armed with "do-ocratic" principles such as participatory governance, autonomy in work, technological creativity and free access to information, is an effective tool for achieving profound and lasting social change.

In this chapter we distinguish "political" actions from "economic" ones. This division is of course artificial: self-governance and the commons are recursively intertwined. However, separating terms enables a clearer delineation of recurrent tensions between social change today and tomorrow, between grassroots activism and electoral politics, between the commons for capital and the commons as the germ form for a postcapitalist society. "If the cell form of capitalism is the commodity, the cellular form of a society beyond capital is the common," writes Nick Dyer-Witheford. "A commodity is a good produced for sale, a common is a good produced, or conserved, to be shared" (2007, p. 82). We agree with Dyer-Witheford: the commons transcend the commodity form. Nonetheless digital capitalism has thrived through the commodification of knowledge, but also through the erosion of the commodity form. One only needs to consider the free services provided to users by Google or Facebook, or the importance of free and open source software in the Internet economy. In no sense are these "commodities" in the Marxist sense: "a two-sided entity, use-value and exchange-value" (Marx, 1976). They are quite the opposite: use value and exchange value are disconnected, as firms do not extract value directly by selling software or online services enjoyed by users. In fact, many goods "produced, or conserved, to be shared" are now fully integrated in the digital economy. 
This raises a provocative question: what if the commons now enable the metastasizing of a capitalism beyond the commodity form into the heart of peer production projects?

Before developing these ideas, we address the political manifestations of peer production, understood in terms of autonomous self-direction, participatory and direct forms of democracy which privilege egalitarian principles, member governance, and the collective resolution of issues. A distinction can be made between distributed and selfgoverned politics which take place outside the conventional arena of parties and elections, and that which directly engages with this conventional arena. We address each of these forms in turn. We purposely restrict our discussion to the actions of peer producers which lead to social change, and only touch briefly on social movements and protest actors' use of peer production. Readers interested in this second topic are invited to read our companion chapter on "Peer Production and Collective Action" (Milan, this volume).

\section{Self-Governance Outside the Political System: Prefigurative Politics}

Prefiguration signifies that ends are embodied in means: actions occurring now reflect the kind of future society sought out by those involved. We briefly touch on social movement actors, then review how different categories of peer producers engage in prefigurative political action.

\subsection{Protest: The endless meeting has begun}

The distributed status of social movements arguably predates the democratization of the Internet in the mid-1990s. World system theorists suggested in the late 1980s that it was no longer necessary for global social movements to be contained by the nation-state; rather, they could be transnationally organized as a network (Arrighi, Hopkins, \& Wallerstein, 1989). The development of the Internet was deemed by Castells (2004) to enable values such as diversity, decentralisation, informality and grassroots democracy 
rather than centralisation and hierarchy, so that information and communication technologies fit perfectly the ideological and organizational needs of social movements.

Continuing this line of argument, recent social movements have been described as having embraced peer production principles; in particular, the participatory quality observed in offline collective action led some commentators to opine that the "Occupy movement and the Wikipartido have explicitly modelled their organization on wikis and other peer production communities in an effort to facilitate deeper participation and democracy" (Shaw \& Hill, 2014, p. 202) For a generation of activists and researchers brought up believing that the Internet enables non-hierarchical participation, it was but one step to detect a connection between the networked and leaderless protests that have erupted since 2008 - such as the Arab Spring, Occupy Wall Street, and the countless occupations of city squares around the world - and peer production.

We should however be careful not to project undue influence onto peer production. Polletta describes in her book Freedom is an Endless Meeting (2004) a common attribute participatory democracy - connecting 20th century labor, civil rights, student, feminist, and economic justice movements. There is a direct thread running from Green politics to the Direct Action Network which challenged the WTO in 1999 and helped to inspire Global Justice, and Occupy Wall Street (Juris et al., 2012). Indeed, many social movements have been organized through decentralized, diffuse, and leaderless networks since the 1960s (Calhoun, 1993; Gerlach \& Hine, 1970), with the French Gilets Jaunes movement of 2018-2019 representing a notable recent example.

Distributed and anti-authoritarian network structures can be more fair than topdown systems, and they allow more space for autonomous investments by participants. They conform to the prefigurative preeminence of tactics (how shall we best organize direct democracy during this meeting?) over strategy (how can we achieve our long-term 
goals?). In the age of "mass self-communication" (Castells, 2009), the shift from the DIY Independent Media Centers of the early 2000s to social media results in a loss of autonomous control over the media platforms used to coordinate and report on protests. With "connective action" whereby the network becomes the organization and participants share emotionally resonant content with others (Bennett \& Segerberg, 2013), activism ends up being another digital trace to be data-mined and marketed, and we find ourselves very far from participation and transparency. Moreover, the reliance on technology can reinforce existing social divisions: in OWS there was a clear contrast between the informal, fast-paced and individualized modes of participation used by predominantly privileged actors and the more formal grassroots modes of communitarian organization favored by people of color (Juris et al., 2012).

\subsection{Peer projects}

Peer production projects such as free and open source software (F/OSS) and Wikipedia are also an example of such prefigurative politics. Where social movement organizations aim to lessen exploitation and oppression in the offline world, participants in collaborative projects see their online activities as the means to performatively achieve change, by engaging in non-exploitative practice, such as the production or dissemination of non-proprietary commons. This kind of subjective micro-politics challenges traditional categorizations of political action, representing a type of "subactivism" which does not seek conventional political change but rather "personal empowerment, seen as the power of the subject to be the person that they want to be in accordance with his or her reflexively chosen moral and political standards" (Bakardjieva, 2009: 96). Traditionally subactivism in peer production has taken the shape of issues which everyone agrees on, such as “opposition to proprietary software or technology and associated intellectual property rights (...) pared with a rejection of surveillance and censorship" (Delfanti \& Söderberg, 
2018), Chris Kelty (2008) has argued that these technical and legal assemblages are produced by "recursive publics", that is

a public that is vitally concerned with the material and practical maintenance and modification of the technical, legal, practical, and conceptual means of its own existence as a public; it is a collective independent of other forms of constituted power and is capable of speaking to existing forms of power through the production of actually existing alternatives (Kelty, 2008: 3))

Peer projects have also been defined as “ethical-modular organizations” (O’Neil, 2015) as participants are initially motivated by intrinsic, non-financial motivations such as helping humanity, self-fulfillment, and community validation. Labor is communal and outputs are orientated towards the further expansion of the commons; while the commons are the chief resource in this mode of production (Söderberg \& O’Neil, 2014). Peer governance is “distributed" or "modular". All online ethical-modular organizations adopted the computational characteristic of being broken up into distinct autonomous components which can be developed in parallel, allowing asynchronous investments of individuals with varying competencies, who can "define the nature, extent, and timing of their participation in the project" (Benkler, 2006, p. 100).

Since ends are embodied in means, close attention is paid to participatory processes. Combining individual autonomy and the efficient coordination of action has been a challenge for anti-authoritarian groups since the 1970s, when openly debating rules in such groups was shown to be necessary in order to avoid what feminist activist Jo Freeman (1972) called the "tyranny of structurelessness": the absence of explicit rules facilitates power being monopolized by informal cliques which manipulate deliberations 
and decision-making. A more recent study of several hundred wikis - not including Wikipedia - found that the governance of peer projects led to self-preservation tactics (Shaw \& Hill, 2014). The authors suggested that this conformed to the so-called "iron law of oligarchy" which holds that as organizations grow in size, a small group of early entrants increasingly concentrates power in a way that runs contrary to the interests of the majority. Others had made a similar point about minority control as regards Wikipedia (Kittur et al., 2007; Ortega, 2009). This leads to negative consequences in terms of justice (O’Neil, 2009) and recruitment (Halfaker et al., 2013).

However, an important distinction is that some forms of peer production are more vulnerable to these harms than others. Concentration of power occurs mostly in projects characterized by vast asymmetries in engagement and rights between participants, by the tolerance for anonymous and/or ill-informed contributions, and where the only costs of poor contribution quality are the time and effort of a limitless army of fact-checkers. In contrast, when contributions are not textual and easily reverted, but computational and potentially destructive, project participants must be identifiable, and known to be technically competent. Their equal rights in decisions are then guaranteed (for example, all Debian Developers, who have gone through the New Member Process, have voting rights in the project) and concentrations of power accrued because of early entry are much less prevalent.

Scholars who examined F/OSS communities such as Debian (O’Mahony \& Ferraro, 2007) and FreeBSD (Dafermos, 2012) focused on the "succession problem", on the evolution from an informal and centralized form of legitimacy, organized around the figure of the charismatic founder, to a more decentralized and democratic mode. In a book (2009) and articles (2011a, 2011b, 2014) O’Neil also analyzed authority in self-governed, anti-authoritarian projects. He suggested that self-governance in online projects is distinct 
from the interest or cause-oriented collective identity found in social movements (Ackland \& O’Neil, 2011; Melucci, 1995): it depends on a specific type of connection or integration between participants. Affective integration connects participants and an exceptional being, in which case the genius of the founder is emphasized; Linus Torvalds remains the archetype. Democratic integration unites a community of equals, with no distinction of class, gender or age, in which case collectively elaborated and implemented procedures are what matter. The hacker-charismatic and procedural modes of authority corresponding to these modes of integration enable controlling actions such as rejections of contributions and exclusions of participants to be made legitimately in the eyes of the community.

In recent years, evolving attitudes, the efforts of feminist F/OSS practitioners and the rise of the Maker movement have allowed a better understanding of the intersectionality of domination in F/OSS (see the chapters on Free and Open Source Software by Couture and on Feminist Peer Production by Toupin, both in this volume). There is a simple reason for why sexism long went unchallenged in F/OSS projects: sexism does not challenge the symbolic integration between participants. This integration is only contradicted when participants appear to be basing expert claims on qualifications issuing from outside the project, or as better informed about important administrative decisions than others. Authority is then perceived to reproduce offline separations and hierarchies, and participants formulate critical reminders, in line with the core meritocratic principles of the hacker ethic (Levy, 1984). Legitimacy in collaborative projects constitutes itself in response to critique: in the realm of knowledge, the critique of external expertise forms the basis for the individualized, hacker-charismatic authority of founders who know the project inside out. In the realm of justice, the critique of opaque deliberations and decisions forms the basis for the collective, procedural authority of administrators who implement community decisions (O’Neil, 2014). 
Therein lies autonomous online projects' subactivist potency. Hacker expertise is meritocratic. The only criterion is technical excellence, discussants are equal, and deliberations and critiques are public. This expertise resembles the contempt for nonexperts and the cult of efficiency of dominant social actors, but it also constitutes a rejection of the technocratic elite which operates in secret and seldom lets the public interest distract it from advancing industrial and financial concerns. Online peer projects are also governed by procedural authority. Basing authority on practically demonstrated competencies and on the transparency of deliberations and judgements opens the way for a normative critique of the social order. In theory at least, the authority of the better argument and the law being applied irrespective of who one is contrast to wider society, where the "great" laugh at the rules that the "small" observe. That ethical-modular projects need to increase the diversity of their membership does not detract from this achievement.

\subsection{Hacktivism: the perils of anonymity}

There is however a scenario when hostile infiltration can cause maximum damage. When participants in peer produced online protest activity rely primarily on technology, rather than face-to-face meetings, to coordinate actions that run afoul of the law, they run the risk of seeing their network fatally disrupted by a well-placed node in the network. This is precisely what occurred in Anonymous, where an FBI informant took down a wealth of participants in exchange for reduced sentencing (Coleman, 2014). It has been suggested that since online social movements are easily accessible for research purposes, researchers may be tempted to overstate their importance (Rucht, 2004). Some sectors of Anonymous, and other groups such as Telecomix, which were motivated by altruistic and progressive principles, really did help people rising against dictatorial regimes in Egypt and Tunisia (Coleman, 2014). They also disrupted entities aiming to shut down the filesharing site Wikileaks, for instance through "Operation Avenge Assange” (Firer-Blaess, 2016). 
However other sectors of Anonymous held fast to the group's original intention of "trolling" for the "lulz," i.e. provoking "laughter at the expense or the misfortune of others" (Coleman, 2014, p. 31). They made fun of "normies," or people holding mainstream values. This ambition was greatly facilitated by the reduced social costs of espousing provocative opinions online. This resulted in Anonymous providing a fertile ground for the "ironic" rejection of progressive values, for subsequent infiltration by ultrareactionary forces, and for eventual cross-pollination with men's rights, "alt-right," and Nazi ideology (Nagle, 2017). Clearly in liberal democracies in general, and in peer production projects in particular, public debate is greatly diminished by people not having to stand by their opinions.

\subsection{Autonomous and self-managed spaces}

It would be tempting to call any kind of recent radical protest which does not involve hierarchical social movement organizations "peer production.” For example, contemporary protest campaigns are arguably most successful when they are firmly anchored in a physical territory. This was famously the case for the "ZAD" (Zone à Défendre, or Area to Defend) in Notre-Dame-des-Landes in the French Loire-Atlantique department, where the technocratic industrial complex which wanted to build an ecocidal airport was defeated by a coalition of anarchists, environmentalists, and (some) local farmers. By opposing the damaging social and ecological impacts of a hierarchical imposition, a decision made far away by people uninvolved and for the benefit of private capital, this resistance spoke to people across the political spectrum, across ages and lifestyles (Fowler, 2017). However, this campaign lacked a crucial element that would have defined it as "peer production": distributed labor. It thus constituted an inverted image of fablabs and hackerspaces which do establish self-reliant and self-organizing modes of collective production but remain the province of a small minority (see Boeva $\&$ 
Troxler, this volume) which possesses the necessary cultural, economic and social capital. Another example of restricted participation in a concrete alternative is the Open Source Ecology project, which has made freely available the designs of its "Global Village construction set" which comprises construction plans, tools, and industrial machines necessary for the construction of a "small, sustainable civilisation with modern comforts".

The building of autonomous and self-managed spaces echoes the political tradition of libertarian socialism: the ideal of a society based upon collaboration among autonomous individuals, where the role of the market and the state is downplayed. This ideal, which prompted various movements since the 19th century - workers' cooperatives, the kibbutzim, the counterculture of the 1960s, and many others - was revitalized by digital technologies' decentralized affordances. According to this line of thought, the building of a different world will not result from revolutionary actions such as "taking the Winter Palace" (the first act of the Russian Revolution). Emancipation must rather be located deep in the social fabric and consists mainly in the self-organization of civil society apart from the state. The renewal of this utopian vision is arguably what is at stake in the various contemporary forms of peer production (Broca, 2013).

Yet tricky questions remain unanswered. On the one hand, focusing on autonomous enclaves could risk removing active participants from opposition to the system, deterring them from confronting structural inequalities and global power asymmetries, thereby comforting the status quo (Fowler, 2017). On the other hand, the self-sufficiency of these enclaves is debatable to say the least. The state and the market cannot really be discarded, insofar as peer production remains "a proto-mode of production, unable to perpetuate itself on its own outside capitalism" (Bauwens \& Kostakis, 2014). In other words participants in peer production projects cannot escape from society, as the vast majority must find their means of subsistence in the dominant market economy. 


\section{Self-Governance and Engagement in Electoral Politics}

In contrast to the constitution of autonomous enclaves outside of conventional politics, a second type of peer-produced politics engages with conventional politics in the form of parties, campaigning, and presenting lists of candidates for election.

\subsection{The Pirate Parties}

The Pirate Party initially evolved from support for The Pirate Bay file sharing website in Sweden in 2006 around issues such as legalizing file-sharing and protecting "freedom" on the Internet (Fredriksson, 2015). From there various electoral platforms around digital rights, as well as political parties, were created. At the European Parliament elections in June 2009, the party obtained $7.1 \%$ of the votes in Sweden, giving the Pirates two seats in the parliament (Burkart, 2013; Erlingsson \& Persson, 2011). Much like the Greens, Pirates adopted a highly decentralized structure designed to emphasize voluntary organization and relying on open access to party meetings, egalitarian decision-making processes as well as "collective forms of leadership, affirmative action, and close links to new social movements" (Miragliotta, 2015, p. 699 ff.).

Tensions arose around electoral participation and leadership. Self-destructive tendencies in the German Pirate Party were described in a 2014 article in Die Zeit: ingrained distrust towards traditional politics meant that all forms of political representation were viewed with suspicion, even those originating from the party itself. Pirate members elected to four state legislatures were vilified for benefiting from the system (Pham, cited in Fredriksson, 2016). In the early days, the lack of formal processes leading to informal concentrations of power in the hands of cliques also came to the fore (Fredriksson, 2015). Somewhat surprisingly, the issue resurfaced when the participatory decision-making "Liquid Democracy" model was introduced. This digital voting platform 
was supposed to enhance direct democracy within the party but operated much in the same way that administrative power is concentrated on Wikipedia (O'Neil, 2009): a minority of active participants uses its mastery of discursive and administrative codes to effectively concentrate power (Cammaerts, 2015).

\subsection{Radical municipalism and Civic Tech}

Another form of peer-produced electoral engagement hinges around the idea that the municipality is the organizational scale best able to achieve a transition to more concretely democratic ways of living. Whereas mobilizations such as Occupy Wall Street, Nuit Debout and the Greek aganaktismenoi (anti-austerity) movement petered out or lost their radical edge, the Spanish anti-austerity activism of Movimiento 15M/Indignados gained power. In the May 2015 municipal elections, the Mayors of Madrid, Barcelona, Zaragoza, Valencia, A Coruña, Cadiz, Pamplona and Santiago de Compostela were elected through "citizen platforms" (Garcia, 2017: 463). These platforms are distinct from political parties in that they use offline neighborhood assemblies and online democracy platforms (aka "civic tech") to "decide everything from their policy agenda to their organizational structure" (Baird, 2015). Decidim in Barcelona and CONSUL in Madrid, the two most used platforms, follow the F/OSS development model in that they are free to use and modify, and are frequently improved by global and local volunteers. This municipalist movement is attempting to create "radically democratic" (Weareplanc, 2017) grassroots political processes whose distinctive characteristics include co-design, co-ownership, trans-local collaboration, and open access. This is meant to enable a different type of governmentality in which local activists, organizations, councils and citizens benefit from being connected to the global commons movement and other local councils to create participatory and collaborative democratic tools (Husain et al., 2019). 
Two frequent references amongst many actors in this social world are North American social anarchist Murray Bookchin's (1992) proposition that a city should operate as a self-governing commune, and the Kurdish autonomist region of Rojava, also known as the Democratic Federation of Northern Syria (Arafat, 2016). According to proponents, the nationalist struggle for a Kurdish homeland has been surpassed by a municipalist struggle not only for the Kurdish identity but for the overcoming of all religious, sectarian, ethnic, economic, political, gender, national and ecological oppression (Fowler, 2017). Spanish radical municipalists lost power at the 2019 elections, but peer politics continue to play an important role in other countries such as Iceland where Birgitta Jonsdottir and Smari McCarthy's Pirate Party won seats at the Althing at the 2013, 2016, and 2017 elections.

\section{The Economics of the Commons and Labor}

The following section considers the economic aspects of peer production. It first explains why many radical thinkers have considered peer production as the germ of a postcapitalist future. It then critically engages with this vision, arguing that peer production projects are often intertwined with neoliberal digital capitalism, and that commoners regularly fail to address the questions raised by unpaid voluntary labor.

\subsection{The digital commons against informational capitalism}

Elinor Ostrom's Nobel Prize for economics in 2009 contributed to spread the idea that there were alternatives to managing resources only through exclusive private ownership of land and knowledge (Ostrom, 1990; Ostrom \& Hess, 2007). Ostrom helped to make people realize that Hardin's (1968) so-called "tragedy of the commons," whereby self-interest by participants leads to the over-use and destruction of common goods, was in fact a tragedy of ill-managed open access. The main bulk of Ostrom's work was applicable to similar commons as Hardin's pasture, that is to say finite natural resources (such as fish 
stocks in a river) administered by a local community. Such rival resources raise issues linked to their long-time preservation; in contrast digital commons raise issues concerning their production and enrichment (Coriat, 2011). Further, most digital commons are globally available to everyone with an Internet connection, whereas physical commons usually imply that different stakeholders are given different "bundles of rights" (Ostrom \& Schlager, 1992)

Free software is the most famous example of a digital commons (Benkler, 2006). In the 1980s and 1990s, even if it was not explicitly anti-capitalist, the world of free software was positioned as external to capitalist accumulation because of the adoption of nonproprietary licenses such as the GPL. In a knowledge economy that was at the time epitomized by Microsoft, i.e. globally built around the enclosure of information through intellectual property, free software represented a dangerous alternative. It was a radical threat to the dominant logic of capital accumulation, not only in the software industry but in all economic sectors whose business models depend on strong intellectual property rights: cultural industries, pharmaceutical companies, agribusiness, etc. Indeed, insofar as most people working on F/OSS viewed it as an end in itself (Dafermos \& Söderberg, 2009) and were willing to abjurate their exclusive property rights over the resource they had created, they could be portrayed as fierce critics of informational capitalism (Aigrain, 2005). These characteristics led some radical thinkers to theorize that peer production was heralding a post-capitalist society (Söderberg, 2008). André Gorz presented free software hackers as embodying "a practical negation of capitalist social relations" (2003, p. 93). McKenzie Wark described informational capitalism as the dispossession of the collaborative production of the "hacker class" by the communication channels-possessing "vectoral class" through the use of patents and copyright (Wark, 2004). 
Writers in the Italian autonomist tradition were also active in this intellectual space. They described a form of cognitive capitalism where value is placed in what cannot be automated, in the capacity to resolve problems (Moulier Boutang, 2007; Virno, 1996). Intelligence, relationships, emotions, creativity are what matter. This new accumulation system is, however, rife with contradictions. The extension of intellectual property rights, on which accumulation depends, collides with the need to be able to access existing knowledge in order to build new knowledge; the "immaterial" nature of work rarely fits into the institutional logic of waged labor; and standard economic tools become unable to correctly measure the production of economic value (Moulier Boutang, 2007). In a nutshell, a productive "multitude" whose free or waged immaterial labor collectively produces immaterial products is then expropriated by capital (Hardt \& Negri, 2004). All is not lost however, as "through the increasing centrality of the common in capitalist production — the production of ideas, affects, social relations, and forms of life —are emerging the conditions and weapons for a communist project. Capital, in other words, is creating its own gravediggers." (Hardt, 2010: 355)

In contrast to the multifaceted multitude, German activists in the Oekonux (Linux Oekonomy) network were clear: it is peer producers who are the vanguard actors in a historical process leading to the disappearance of capitalism and hierarchy. The nonalienated labor of workers in ethical-modular organizations foretells a society where everyone will be free to work at will (Meretz, 2012; Merten \& Richardson 2001; Rigi, 2013). Oekonuxers attempted to bring together the online and the offline, the old and the new, green and social concerns (Euler, 2016). They defined the exchange value of digital commons as close to zero as they are not a form of property or possession but are defined by their actual use in a social relationship; usage is not founded on reciprocity but contribution (Siefkes, 2009). Revisiting Marx's Critique of the Gotha Programme (2008) 
in which the new capitalism emerges from the old feudal model, Meretz (2012) described peer production as a "germ form" which needs a strong capitalism in order to develop. Common goods represent concrete examples of the proprietary logic of exclusion slowly giving ground to the commons' logic of inclusion. Though the commons depend on capital, the new logic is incompatible with the old logic; it cannot be entirely absorbed (Meretz, 2013): open source software can only be produced openly. At some point, after several stages, the new logic will supersede the old, and become dominant: network effects will start occurring, and people will stop being materially dependent on the old mode of production (Euler, 2016).

This perspective describes a future society without coercion, money and hierarchy unfolding almost mechanically, through the law of history. It also idealizes the power of cooperative commons and foregoes discussions of conflicts, politics and law. Siefkes (2009) suggests that in a commons-based society "when effort is distributed, there will probably be a few tasks that nobody (...) wants to do, say because they are annoying, dirty, dangerous, or just plain boring”. One way to resolve this would be to weigh such tasks higher, "i.e. to count short times of doing such a task as equivalent to longer times of doing other tasks" (Siefkes, 2009). The question of what happens if people refuse or abuse the system is not considered.

All these radical perspectives - be they that of André Gorz, Autonomia-inspired, or issuing from the German left - see today's peer production projects as harbingers of global social change. They often imbue these projects with a decisive political significance which is not always shared by participants themselves, whose involvement can be explained by many factors and is often oriented towards more modest goals (Broca, 2013). Radical thinkers usually define peer production as important because of its prefigurative role. Peer production projects, goes this argument, demonstrate that there is a deep antagonism 
between the new source of economic value - social collaboration through information technologies - and the institutions of contemporary capitalism (Moulier Boutang, 2007). The free circulation of information necessary for immaterial production is the force that will eventually displace private appropriation; a vision that clearly harkens back to the classic marxist view that the conflict between productive forces and relations of production is the main driver of social change.

However, if one considers the available data on peer production and labor in the digital economy, one may doubt whether there is "an antagonism between the networked productive forces and the class relations of digital production" (Fuchs, 2020). It is not a given that, with digital technologies, labor power is reappropriating the means of production, thus becoming more autonomous and less subject to the capitalist forms of discipline and control that dominated the Fordist era (Hardt and Negri, 2018). Instead, it appears that the idea of a parasitic or extractive capitalism, simply expropriating the commons "from the outside," is overly simplistic, and that immaterial production can also be organized within capitalism, providing firms make certain adjustments (Dardot \& Laval, 2014). Instead of discussing whether the commons are on the brink of superseding capitalism, a more relevant question might be: at what point has the threshold for capitalist firms to have thoroughly digested and retooled the commons been reached? In other words, have the digital commons mainly become commons for capital?

\subsection{The commons for capital}

The notion, popular in the 2000s, that cyberspace was a cornucopia brimming over with free or pirated content in effect created in consumers the need to purchase the requisite hardware and bandwidth; and it told them to do so in the name of rebelling against the power of evil corporations, who were intent on protecting their private intellectual property (O’Neil, 2006). As the Apple Computer slogan once infamously had 
it: "Rip. Mix. Burn. It's your music." Parallel trends can be observed in some parts of the IT sector, where it eventually dawned on firms that maintaining a death grip on their intellectual property at all costs was hindering innovation. An informational capitalism strongly relying on intellectual property, Microsoft's capitalism, was thus gradually superseded by a new digital capitalism, Google's capitalism (Broca, 2018), ushering in the new age of the so-called "Openness Ideology" (Lund \& Zukerfeld, 2020) dominated by firms such as Google, Facebook, Red Hat, Coursera and Elsevier. Informational capitalism's profits stemmed from the commodification of information, whereas digital capitalism's innovative business model taught itself to take advantage of free and open resources. In the computing world this process began in 1998, after the Freeware summit in Palo Alto, hosted by O'Reilly \& Associates, during which many key players in the free software community (Linus Torvalds, Larry Wall, Guido Van Rossum and many others) decided to use the term "open source" in order to eliminate the anti-business overtones of the term "free software" favored by Richard Stallman.

The subsequent integration of peer production into the capitalist economy has taken several forms. New firms such as Red Hat began producing F/OSS whilst offering legal guarantees and services. Red Hat combines waged and volunteer labor in the Fedora project (Birkinbine, 2017). Products are created at a much lower cost than a fully-waged workforce would entail, and Dafermos and Söderberg (2009) argued that a possible aftereffect of this business model would be the advent of a race towards the bottom in the software industry. In fact, this downward pressure on wages and working conditions in the computer sector has not materialized. Whether traditional Marxist schemata still apply is an open question: firms are not appropriating F/OSS code, which is accessible to all. This is quite different from the situation of proletarians who are dispossessed from the fruits of their labor (Broca, 2013; O’Neil, 2015). In this case the exchange seems to be mutually 
profitable, even if the goods being swapped - economic profits for the firms, selfrealization for the developers - are different. It could even be argued that Red Hat creates an environment where developers can play with passion (Lessig, 2008).

Existing IT firms such as IBM also began adopting Linux, abandoning traditional protection strategies in which value is safeguarded through copyright. F/OSS has now become the "roads and bridges" (Egbahl, 2016) of the digital economy, a "digital infrastructure" that is essential for contemporary commercial activity. From the developer's perspective, participation facilitates integration into the labor market: experience in F/OSS helps with recruitment by IT firms and F/OSS is a source of lifelong learning and support for employees. Many firms no longer sell information goods but generate behavioral data for marketing or algorithmic intermediating between providers and consumers of goods and services (Broca, 2018). Recent examples of firm investments include Google adopting Debian as its internal operating system instead of Ubuntu in 2017, Microsoft buying the F/OSS GitHub repository (where 28M F/OSS developers uploaded code in 2018) for \$7.5M, and IBM buying the Red Hat the same year for \$34M. These striking numbers clarify the enormous economic value of open digital infrastructures (Alcaras, 2019).

Further, $85 \%$ of Linux code is now written by firm employees (Linux Kernel, 2019) and the largest block of uploads to GitHub are made by firm employees (O'Neil et al., 2019a). This type of capitalist engagement - firms paying the salaries of developers to produce F/OSS - is significant, as it reaches deep into projects and raises the issue of the subsistence of peer producers (Broca, 2018; O’Neil et al., 2020). It also challenges conventional understandings of labor (Marx, 1976). In the present case, labor appears to be hybrid, being both "alienated" since it is sold to firms, yet "not alienated" or "communal" as workers work cooperatively and democratically to produce commons (O’Neil, 2015). 
Maurel (2018) argues that projects such as Linux becoming enmeshed with large IT firms potentially compromises project self-governance, as employee-developers are formally subordinated to their employers. In contrast for Mansell and Berdou (2010) workers being paid by firms to contribute to the commons does not affect the "cooperative spirit' of projects; nor can these workers prevent the results of labor from being socialized into commons. Indeed, Debian Developers paid wages by firms to develop F/OSS systematically professed a stronger allegiance to the project, which they had been associated with longer than any employer (O’Neil et al., 2019b).

\subsection{Accounting for unpaid voluntary labor}

For Richard Stallman, whose opinions have historically been highly influential in this debate, F/OSS produced by free labor will always be preferable to non-free software produced by decently paid waged labor: the defense of the "four freedoms" (to use, study and change, redistribute, and distribute modified versions of software) matters more than the fair distribution of profits stemming from software development (Broca, 2018). This normative stance was made very early in the history of free software. In the $G N U$ Manifesto, R. Stallman thus contends that "there is nothing wrong with wanting pay for work, or seeking to maximize one's income", but only "as long as one does not use means that are destructive'. Indeed, “extracting money from users of a program by restricting their use of it is destructive" (Stallman, 1985). Over the years, every time he has been asked to comment on the valuation of open source companies and the fact that they benefit from unpaid voluntary labor, R. Stallman has given the same answer: these issues are secondary. They are mainly "a distraction from what really matters: that these programs (e.g. free software) are available for everyone to use in freedom and community" (Stallman, 2018). In other words, the free software movement should consider software as resources upon which users have certain rights, not as products of a labor that deserves 
monetary retribution. Hence, free riding that is not based on enclosing code but on free labor is not a major concern for R. Stallman.

Yochai Benkler's $(2006,2013)$ near-canonical accounts of peer production similarly insist on the altruistic or passionate intrinsic motivations of peer producers, who will need to find means of subsistence outside peer production. A few voices have also risen from within the F/OSS community against generating funds to compensate developers for their labor. The simplicity and elegance of F/OSS code is born of necessity, goes this argument; the introduction of money means developers will start embellishing code to fill the amount raised, resulting in "consultant ware", needlessly complex software which requires expert advice to run; if intrinsic motivations are replaced by the marketplace, the "magic and beauty" of F/OSS will be lost (Heinemier Hansson, 2013).

In contrast, other actors in the F/OSS community have claimed that "open source has a working-for-free problem", with some launching firms with the explicit aim of providing independent open source maintainers with a reliable income (Pennington, 2019). In the same vein a candidate for the 2019 Debian Project Leader election proposed in his platform that Debian Developers should be able to make Debian their careers if they chose to, thanks to increased firm involvement and grants (Michlmayr, 2019). A few months later the issue was revived on Debian's "Project" email list where it generated a robust debate, with some Developers arguing that introducing financial rewards within the project risked distorting Debian's emergent and self-directed means of determining the relative value of project goals (debian-project, 2019).

Such perspectives acknowledge the reality of firm support for F/OSS but argue that the highly distributed nature of this support, as well as the ethical norms of F/OSS, guarantee project autonomy. Yet the rejection of financial rewards inside the Debian project fails to address the social stratification which results in $1.5 \%$ of F/OSS developers 
being female, against 28\% for proprietary software (David et al., 2003; Dryden, 2013). The relationship of ethical-modular organizations to existing social hierarchies is seldom evoked in terms of class, with gender often framed as the most significant source of power imbalances (Nafus, 2012). That voluntary labor in ethical-modular organizations is only accessible to a minority is obvious. However, it is not only women who do not have the disposable income, cultural capital, or family support to engage in unpaid labor (Huws, 2013).

Not only does the rejection of financial rewards reproduce class and gender inequalities, it also hinders the evolution of the commons into an autonomous mode of production. If peer production is to transform society and not simply provide digital capitalism with a pool of free labor, it cannot depend only on volunteer work, but must invent institutions and metrics to compensate peer labor and measure value. This does not mean that voluntary unpaid labor should be abolished. In the foreseeable future, it will probably remain a necessary component of numerous peer production projects. But peer production thinkers and practitioners need to devise viable mechanisms to make the commons economy more robust and more autonomous, in order to challenge the structural imbalance between what digital capitalism obtains from the commons, and what it gives back.

\section{Conclusion: Towards a Sustainable Contribution Society?}

Neoliberal capitalism persists because of its hegemony, because of the neutralization of its politics into common sense, and because of its infiltration of the perceptions and imaginations of people who inhabit it (Fowler, 2017). Its rationality, efficiency or ability to provide wellbeing do not keep it alive; capitalism survives thanks to 
its economic and political power and the lack of a coherent, compelling and believable alternative and counter-narrative.

This chapter has argued that, there are reasons to believe that peer production and the commons could be part of such an alternative. However, social change is neither a simple effect of technological innovation, nor is it the mechanical outcome of the contradiction between productive forces and relations of production. The capacity of peer production to inform a believable and meaningful alternative thus depends on peer producers' ability to find new allies in civil society, unions, and government, as well as on their capacity to invent and keep building new practices, organizations, economies and political strategies. These and related questions are explored in this Handbook's final chapter. 


\section{References}

Ackland, R., \& O’Neil, M. (2011). Online collective identity: The case of the environmental movement. Social Networks, 33(3): 177-190.

Aigrain, P. (2005). Cause commune. Paris, Fayard.

Alcaras, G. (2019). Le Travail du Code Source - Une socio-histoire de git, de 1995 à nos jours. Thèse de sociologie en cours, EHESS.

Arafat, H. (2016). "Rojava' no longer exists, "Northern Syria" adopted instead.

Kurdistan24 http://www.kurdistan24.net/en/news/51940fb9-3aff-4e51-bcf8-

b1629af00299/-rojava--no-longer-exists---northern-syria--adopted-instead-

Arrighi, G., Hopkins, T. K., \& Wallerstein, I. (1989). Anti-Systemic Movements. London: Verso.

Baird, K.S. (2015). Rebel cities: the citizen platforms in power. Red Pepper. https://www.redpepper.org.uk/rebel-cities-the-citizen-platforms-in-power/

Bakardjieva, M. (2009). Subactivism: Lifeworld and politics in the age of the internet. The Information Society, 25: 91-104. 
Baldwin, C., \& Clark, K. (2000). Design Rules, Volume I: The Power of Modularity. Cambridge, MA: MIT Press.

Bauwens. M., \& Kostakis, V. (2014). From the communism of capital to capital for the commons: Towards an open co-operativism. Triple $C, 12(1)$. http://www.triple-c.at/index.php/tripleC/article/view/561

Benkler, Y. (2006). The Wealth of Networks: How Social Production Transforms Markets and Freedom. Yale: Yale University Press.

Benkler, Y. (2013). Practical anarchism: Peer mutualism, market power, and the fallible state. Politics \& Society, 41(2): 213-251.

Bennett, L. (2004). Communicating global activism. In: van de Donk, W., Loader, B., Nixon, P.G., Rucht, D. (Eds.), Cyberprotest. New Media, Citizens and Social Movements (pp. 109-128). London and New York: Routledge.

Bennett, L., \& Segerberg, A. (2013). The Logic of Connective Action: Digital Media and the Personalization of Contentious Politics. New York, NY: Cambridge University Press.

Birkinbine, B. (2017). From the commons to capital: Red Hat, Inc. and the business of free software. Journal of Peer Production, 10. http://peerproduction.net/issues/issue-10-peerproduction-and-work/from-the-commons-to-capital/

Boltanski, L. (2011). On Critique. A Sociology of Emancipation, Polity, Cambridge, UK. 
Bookchin, M. (1992). From Urbanization to Cities, Toward a New Politics of Citizenship, Guildford: Cassell.

Broca, S. (2013). Utopie du logiciel libre. Du bricolage technologique à la réinvention sociale. Neuvy-en-Champagne: Le passager clandestin.

Broca, S. (2018). Du modèle du logiciel libre au modèle productif des communs. Les licences pair à pair contre le free software? Working Paper 9, Projet EnCommuns.

Burkart, P. (2013). Pirate Politics. Cambridge, MA: MIT Press.

Calhoun, C. (1993). "New Social Movements" of the early nineteenth century. Social Science History, 17(3): 385-427.

Cammaerts, B. (2015). Pirates on the liquid shores of liberal democracy: Movement frames of European Pirate Parties. Javnost - The Public, 22(1): 19-26.

Castells, M. (2004). The Power of Identity. The Information Age: Economy, Society and Culture Vol. 2, 2nd edition. Blackwell, London.

Castells, M. (2009). Communication Power. Oxford University Press, Oxford.

Coleman, G. (2014). Hacker, Hoaxer, Whistleblower, Spy: The Many Faces of Anonymous. London: Verso Books. 
Coriat, B. (2011). From natural-resources commons to knowledge commons. Common traits and differences. WP 2011-4. http://www.mshparisnord.fr/ANR$\underline{\text { PROPICE/documents.html }}$

Dafermos, G. (2012). Authority in peer production: The emergence of governance in the FreeBSD project. Journal of Peer Production, 1. http://peerproduction.net/issues/issue1/peer-reviewed-papers/authority-in-peer-production/

Dafermos, G., \& Söderberg, J. (2009). The hacker movement as a continuation of labour struggle. Capital \& Class, 33(1): 53-72.

Dardot, P., \& Laval, C. (2014). Commun. Paris : La Découverte.

Delfanti, A., \& Söderberg, J. (2018). Repurposing the hacker. Three cycles of recuperation in the evolution of hacking and capitalism. ephemera, 18(3): 457-476.

Dryden, A. (2013). The ethics of unpaid labor and the OSS Community, 13 Nov. http://www.ashedryden.com/blog/the-ethics-of-unpaid-labor-and-the-oss-community

Dyer-Witheford, N. (2007). Commonism. Turbulence, 1. http://turbulence.org.uk/turbulence-1/commonism/ Eghbal, N. (2017). Roads and Bridges: The Unseen Labor Behind Our Digital Infrastructure. NYC: Ford Foundation. 
Erlingsson, G.O., \& Persson, M. (2011). The Swedish Pirate Party and the 2009 European Parliament election: Protest or issue voting? Politics, 31(3): 121-128.

Euler, J. (2016). Commons-creating society: On the radical German commons discourse. Review of Radical Political Economics, 48(1): 93-110.

Firer-Blaess, S. (2016). The Collective Identity of Anonymous: Web of Meanings in a Digitally Enabled Movement. PhD dissertation. Uppsala. http://urn.kb.se/resolve?urn=urn:nbn:se:uu:diva-292734</div>

Fowler, K. (2017). Tessellating Dissensus: Resistance, Autonomy and Radical Democracy - Can transnational municipalism constitute a counterpower to liberate society from neoliberal capitalist hegemony? Masters dissertation. Schumacher College.

Fredriksson, M. (2015). The Pirate Party and the politics of communication. International Journal of Communication, 9: 909-924.

Fredriksson, M. (2016). Pirate politics between protest movement and the parliament. Ephemera, 16(2): 97-114.

Freeman, J. (1972). The tyranny of structurelessness. Berkeley Journal of Sociology, 17, 151-165.

Fuchs, C. (2020). Communicative Socialism/Digital Socialism. TripleC 18(1): 1-31. 
Garcia, B. (2017). New citizenship in Spain: From social cooperation to self-government. Citizenship Studies, 21(4): 455-467.

Gerlach, L. R., \& Hine, V.H. (1970). People, Power, Change: Movements of Social Transformation. Indianapolis: Bobbs Merrill.

Gitlin, T. (1980). The Whole World Is Watching: Mass Media in the Making and Unmaking of the New Left. Berkeley: University of California Press.

Gorz, A. (2003). L'immatériel: Connaissance, valeur et capital. Paris : Galilée.

Halfaker, A., Geiger, R. S., Morgan, J. T., \& Riedl, J. (2013). The rise and decline of an open collaboration system: How Wikipedia's reaction to popularity is causing its decline. American Behavioral Scientist, 57, 664-688.

Hardin, G. (1968). The tragedy of the commons, Science, 162: 1243-1248.

Hardt, M. (2010). The common in communism. Rethinking Marxism, 22(3): 346-356.

Hardt, M. \& Negri, T. (2018). The Powers of the Exploited and the Social Ontology of Praxis. TripleC 16(2): 415-423.

Husain, O.S., Franklin, A., \& Roep, D. (2019). Decentralising geographies of political action. Civic tech and place-based municipalism. Journal of Peer Production, 13. 
http://peerproduction.net/issues/issue-13-open/peer-reviewed-papers/decentralisinggeographies-of-political-action/

Juris, J. S., Ronayne, M., Shokooh-Valle, F., \& Wengronowitz, R. (2012). Negotiating power and difference within the 99\%. Social Movement Studies, 11(3-4): 434-40.

Kelty, C. (2008) Two Bits: The Cultural Significance of Free Software. Durham, NC: Duke University Press.

Kittur, A., Chi, E., Suh, B., \& Mytkowicz, T. (2007). Power of the few vs. wisdom of the crowd: Wikipedia and the rise of the bourgeoisie. In: Proceedings of Alt. CHI. New York, NY: ACM.

Kreiss, D., Finn, M., \& Turner, F. (2011). The limits of peer production: Some reminders from Max Weber for the network society. New Media \& Society, 13: 243-259.

Lessig, L. (2008). Remix: Making Art and Commerce Thrive in the Hybrid Economy, New York: The Penguin Press

Levy, S. (1984). Hackers: Heroes of the Computer Revolution. New York: Doubleday.

Linux Kernel Patch Statistic (2019). http://www.remword.com/kps_result/

Lund, A. \& Zukerfeld, M. (2020) Corporate Capitalism's Use of Openness. Basingstoke: Palgrave Macmillan. 
Mansell, R., \& Berdou, E. (2010). Political economy, the internet and FL/OSS development. In: Hunsinger, J., Allen, M., \& Klastrup, L. (Eds.) International Handbook of Internet Research (pp. 341-362). Amsterdam: Springer.

Marx, K. (1973). Grundrisse. Harmondsworth : Penguin.

Marx. K. (1976). Capital, Vol. 1. London: Pelican.

Marx, K. (2008). Critique of the Gotha Programme. XX: Wildside Press.

Maurel, L. (2018). Les Communs numériques sont-ils condamnés à devenir des Communs du capital? Scinfolex, 24 June. https://scinfolex.com/2018/06/24/les-communs-numeriquessont-il-condamnes-a-devenir-des-communs-du-capital/

Melucci, A. (1995). The Process of collective identity. In Johnston, H., \& Klandemans, B. (Eds.), Social Movements and Culture (pp. 41-63). Minneapolis, MN: University of Minnesota Press.

Meretz, S. (2012). Ten patterns developed by the Oekonux movement. Journal of Peer Production, 1. http://peerproduction.net/issues/issue-1/debate-societal-transformation/tenpatterns-developed-by-the-oekonux-project/ 
Meretz, S. 2013. Commonismus begreifen, Oder: Die bestimmte negation des kapitalismus. Transformationsseminar. Hiddinghausen. http://keimform.de/2013/commonismusbegreifen

Michels, R. (1915). Political Parties: A Sociological Study of the Oligarchical Tendencies of Modern Democracy. New York, NY: Hearst.

Michlmayr, M. (2019) Platform. https://www.debian.org/vote/2019/platforms/tbm

Miragliotta, N. (2015). Minor organizational change in Green parties: An Australian case study. Party Politics, 21(5): 699-711.

Moulier Boutang, Y. (2007). Le Capitalisme Cognitif: La nouvelle grande transformation. Paris: Éditions Amsterdam.

Nafus, D. (2012). 'Patches don't have gender': What is not open in Open Source software. New Media \& Society, 14(4): 669-683.

Nagle, A. (2017). Kill All Normies: Online Culture Wars from 4chan and Tumblr to Trump and the Alt-Right. NY: Zero Books.

O’Mahony, S., \& Ferraro, F. (2007). The emergence of governance in an open source community. Academy of Management Journal, 50: 1079-1106. 
O’Neil, M. (2006). Rebels for the system? Virus writers, general intellect, cyberpunk and criminal capitalism. Continuum: Journal of Media \& Cultural Studies, 20(2): 225-241.

O'Neil, M. (2009). Cyberchiefs: Autonomy and Authority in Online Tribes. London: Pluto Press.

O’Neil, M. (2011a). Wikipedia and authority. In Lovink, G., \& Tkacz, N. (Eds.) Critical Point of View Reader (pp. 309-324). Amsterdam: Institute of Network Cultures.

O’Neil, M. (2011b) The sociology of critique in Wikipedia. Journal of Peer Production, 0. http://peerproduction.net/issues/issue-0/peer-reviewed-papers/sociology-of-critique/

O’Neil, M. (2014). Hacking Weber: legitimacy, critique and trust in peer production. Information, Communication \& Society, 17(7): 872-888.

O’Neil, M. (2015). Labour out of control. The political economy of capitalist and ethical organizations. Organization Studies, 36(12): 1627-1647.

O’Neil, M., Cai, X., Muselli, L., Raissi, M., \& Zacchiroli, S. (2019a). Should free-riding IT firms start 'giving back'? Mapping the firm and F/OSS co-production network. Under review.

O’Neil, M, Muselli, L., Raissi, M., \& Zacchiroli, S. (2019b). “Open Source has won and lost the war": Justifying commercial-communal hybridisation in a F/OSS project. Under review. 
Ortega, F. (2009). Wikipedia: A Quantitative Analysis. PhD thesis. Universidad Rey Juan Carlos.

Ostrom, E. (1990). Governing the Commons: The Evolution of Institutions for Collective Action. New York, NY: Cambridge University Press.

Ostrom, E., \& Schlager, E. (1996). The formation of property rights. In: Hanna S., Folke, C., \& Mäler, K.-G. (Eds.), Rights to Nature (pp. 127-156). Washington, DC: Island Press.

Ostrom, E., \& Hess, C. (2007). Understanding Knowledge as a Commons. Cambridge, MA: The MIT Press.

Pennington, H. (2019). Open source has a working-for-free problem. https://blog.tidelift.com/open-source-has-a-working-for-free-problem

Polletta, F. (2004). Freedom Is an Endless Meeting: Democracy in American Social Movements. Chicago: University of Chicago Press.

Polletta, F., and Jasper, J. (2001). Collective identity and social movements. Annual Review of Sociology, 27: 283-305.

Rigi, J. (2013). Peer production and Marxian communism: Contours of a new emerging mode of production. Capital \& Class, 37: 397-416. 
Rucht, D. (2004). The quadruple "A": Media strategies of protest movements since the 1960s. In: van de Donk, W., Loader, B., Nixon, P.G., \& Rucht, D. (Eds.), Cyber-protest. New Media, Citizens and Social Movements. London and New York: Routledge.

Söderberg, J. (2008). Hacking Capitalism: The Free and Open Source Software Movement. London and New York: Routledge.

Söderberg, J., \& O’Neil, M. (2014). Introduction. In: Söderberg, J., \& Maxigas (Eds.), Book of Peer Production (pp. 2-3). Göteborg: NSU Press.

Shaw, A., \& Hill, B. M. (2014). Laboratories of oligarchy? How the iron law extends to peer production. Journal of Communication, 64(2): 215-238.

Siefkes, C. (2009). The commons of the future: Building blocks for a commons-based society. The Commoner. http://www.commoner.org.uk/wpcontent/uploads/2009/03/siefkes_future-commons.pdf

Stallman. R. M. (1985). The GNU Manifesto.

https://www.gnu.org/gnu/manifesto.en.html

Stallman. R. M. (2018). Private conversation with Rob Lucas. Posted on the mailing list Nettime with permission.

https://nettime.org/Lists-Archives/nettime-1-1811/msg00049.html 
Virno, P. (1996). Notes on the general intellect. In: Makdisi, S., Casarino, C., \& Carl, R. (Eds.), Marxism beyond Marxism. London: Routledge.

Wark, M. (2004). A Hacker Manifesto: Version 4.0.

http://subsol.c3.hu/subsol_2/contributors0/warktext.html. 